\title{
When journalists lose their foothold
}

\section{Swedish and Norwegian verification scandals in \#MeToo-movement coverage}

\author{
SIGURD ALLERN \\ University of Oslo \\ ESTER POLLACK \\ Stockholm University
}

\section{Abstract}

The global \#MeToo movement exposed the widespread structural problem of sexual harassment, which was also the case in Sweden and Norway. Across the various sectors of working life, women were able to identify with the call. This perspective, however, was undermined in the public sphere when person-centred scandal stories about a few powerholders and media celebrities took over. In addition, a lack of verifiable documentation - and uncritical use of anonymous sources - ignited renewed debates about the ethical standards of professional journalism. This article discusses two alleged \#MeToo cases: Aftonbladet's dramatic and unfounded accusations against the theatre CEO Benny Fredriksson and $V G$ 's misuse and manipulation of a "bar-dance" episode involving the Norwegian Labour politician Trond Giske. Both media stories developed into "critical incidents", resulting in public criticism, self-examination and discussions around ethical rules and regulation. 


\section{KEYWORDS}

\#MeToo, scandal, verification, media ethics, market-driven journalism

\section{Introduction}

The international \#MeToo movement, launched in the first weeks of October 2017, quickly garnered widespread public response in Sweden and Norway. After sharing their stories in closed forums on social media, women from a wide range of occupational groups and work environments made their testimonies public in legacy media under several related hashtags, among others \#silencerecording (actors in film, theater and television), \#withwhatright (lawyers/ jurists), \#whenmusicissilenced (music branch) and \#inthecorridorsofpower (politicians).

Allegations of sexual misconduct and abuse were described as men's misuse of power concerning women in weaker positions, often women who were younger and dependent. In addition, personal experiences were linked to employers' social responsibility and the need for clearer norms against sexual harassment in society (Askanius \& Hartley, 2019 a, b; Hansson et al., 2020; Lindqvist \& Ganetz, 2020; Pollack 2019; Sletteland, 2018; Sletteland \& Orgeret, 2019, 2020).

This development led to a stream of news reports and commentaries in the news media, a coverage that also put journalism, characterised as "a discipline of verification" (Kovach \& Rosenstiel, 2007, p. 79), to a decisive test. While the numerous public testimonies in different industrial and cultural sectors generally practised anonymity concerning both victims and abusers and pointed to sexual harassment as a structural societal problem, individual charges against some named and well-known public figures played a central role in many of the reports prioritised by news media organisations. In several cases, a lack of verifiable documentation - and the use of anonymous sources - ignited renewed debates about the ethical standards of professional journalism.

In Sweden, the widespread "outing" of names - followed by person-oriented scandal coverage and media hunts - resulted in a range of complaints to the Press Ombudsman (PO). Cases that the PO deemed to violate its rules were submitted to the Press Council 
(PON) for review and decision-making. ${ }^{1}$ Many of the accused in these stories were politicians, journalists, TV personalities, and persons in cultural institutions. In 22 \#MeToo-related cases, the PON criticised the news media organisations responsible for violations of good editorial practice. According to the then PO, Ola Sigvardsson, a recurring theme in the critique was the publication of harassment claims targeting identified persons, despite weak evidence, often based on allegations from anonymous sources. These harassment claims led to unjustifiable reputational damage (Sigvardsson, 2018). ${ }^{2}$

One of the most controversial media reports was a news story published December 5, 2017, in Aftonbladet, the news outlet with the highest readership in Sweden. The CEO of Kulturhuset Stadsteatern (Stockholm House of Culture \& City Theatre) in Stockholm, Benny Fredriksson, was on this front-page reportage, accused of being "an erratic dictator who pushed forward an abortion, sexually harassed staff and repeatedly let male actors commit abuse without action" (Kerpner, 2017). The severity of the accusations was underlined in two editorial commentaries. Two days after the publication, Fredriksson resigned from his position. Some months later, in March 2018, he took his own life. His death, which occurred before the PO and PON considered the complaint from his family about Aftonbladet's coverage of the case, sharpened the public debate about press ethics and publication practises.

In Norway, "naming and shaming" was less common in legacy media than in Sweden, and the relatively few highlighted cases in 2017/2018 concerned politicians (Sletteland, 2018). Different political parties and organisations reported, however, that they had received several internal notifications of harassment charges, but few of the names were published. Only one \#MeToo complaint - related to publications in three news media outlets - was appraised in 2018 by the Norwegian Press Complaints Commission (Pressens Faglige Utvalg, PFU) (Jortveit, 2018). The three media organisations were all criticised for violating good press practices in their source work. ${ }^{3}$

One main exception to this relatively careful publication practice of "naming and shaming" was a comprehensive and intense media coverage of several party-internal harassment charges against Trond Giske, one of two deputy leaders of the Norwegian Labour Party, and a member of the Norwegian parliament, Stortinget. He was also the party's fiscal policy spokesperson and had previously held different 
ministerial positions in two Labour-led governments. Early in 2018, after weeks of media headlines about some charges, followed by discussions in the Labour Party's leadership, he resigned from his party leadership positions.

Approximately one year after his downfall, $V G$, Norway's marketleading online news outlet, presented a new negative story about Giske's behaviour towards women. The documentation was based on a six-second-long mobile video recording from a local bar in Oslo, which showed him smiling and dancing firmly behind a young woman.

However, this alleged "\#MeToo story" was, as VG was eventually forced to admit, based on false premises. The \#MeToo framing was misleading, made with the help of blurry video pictures and a constructed "citation" from the woman captured dancing with Giske. The new "Giske scandal" was quickly turned around into a journalism scandal, leading to sharp public debates and critique, not least from journalists in other media outlets.

These two cases - Aftonbladet's dramatic and unfounded accusations against Benny Fredriksson and $V G$ 's misuse and manipulation of the "bar-dance" episode - both developed into "critical incidents" (Tandoc et al., 2021), resulting in public criticism, self-examination, and discussions around ethical rules and regulation. Both cases were discussed by Torbjörn von Krogh (2020) in the context of the tools applied in the follow-up of serious ethical violations.

The news media organisations highlighted in the two cases, Aftonbladet and $V G$, have several features in common. They are owned by the Schibsted Media Group, a listed company based in Norway. Through their history as printed newspapers, they have combined the traditional "tabloid" priority of popular journalism (news, entertainment, and sport) with cultural pages, political commentary, and elements of investigative journalism. During the last decade, $V G$ and Aftonbladet have both succeeded in establishing themselves as the leading online news media outlet in their respective countries. One difference concerning their ideological leanings, however, is that while $V G$ can be characterised as a liberal-conservative news outlet, Aftonbladet has a social-democratic profile in its editorial commentary and cultural pages.

This article aims to compare and analyse the two above-mentioned cases and use them to reflect on ethical dilemmas that regularly arise 
in the news media's coverage of \#MeToo-related cases, especially in news stories based on "naming and shaming". A central ethical question is how journalists can avoid revelations that violate honesty, sincerity, and verification norms.

Media ethics may be interpreted as an effort to combine the market objectives and competition requirements of news organisations with the basic norms of journalism as an institution. This is an often contradictory and challenging task and can easily lead to conflicting goals concerning editorial priorities and moral values (Allern \& Pollack, 2019; Bjerke, 2011; Harcup, 2020, 2007; Phillips et al., 2010; Zelizer, 2017). Nevertheless, the press organisations in Norway and Sweden have traditionally had a pro-active profile in debates about journalism and ethics and have insisted on the value of a self-regulating system independent of government intervention.

The article is organised as follows: First, we further detail the inherent conflicts between different types of journalistic aims, norms, and practices. Second, we take up the ethical norms of truthfulness and verification and discuss how they can be interpreted. Third, we analyse and discuss the two selected cases: "Benny Fredriksson's lost honour" tackles Aftonbladet's unverified accusations, and "Trond Giske's scandalised bar dance" examines VG's attempt to create a political scandal involving Trond Giske through a leaked private video recording and manipulation of a citation. Fourth and finally, we conclude and discuss why news media from time to time lose their foothold and overlook ethical rules concerning fairness and accuracy. ${ }^{4}$

\section{The dual nature of the news media}

Our theoretical point of departure is the two-sided character of news media organisations. Like Janus - the Roman god of beginnings and ends - market-driven journalism has two faces pointing in opposite directions. On the one hand, they are patrons of journalism as an institution; they have ascribed a role as defenders of free speech and disseminators of fact-checked information, and they have an obligation to hold powerholders to account. But, on the other hand, they are competitors for audience attention on the news market and rep- 
resent rival media houses engaged in the production and dissemination of information and entertainment.

In market terms, news media organisations are enterprises that produce and disseminate news content and other media products including advertisements - to audiences. They include printed newspapers as well as online news outlets, television, and radio channels, and journalistic content encompasses different formats and genres. However, what sets the news media apart from other media organisations - such as film companies, subscription video-on-demand services, book publishers, and entertainment channels in radio and television - are primarily their links to journalism as an institution.

In institutional terms, journalism represents social patterns of behaviour spanning across organisations (Ryfe, 2006). These social patterns include genre rules, routines, and internalised norms concerning information gathering, source relations, editorial assessment, and publication. Such features, including ideas about professional, ethical norms, have developed over a long period of time, with expectations regarding the roles of journalists and editors.

In the second part of the last century, the development of press ethics codes in the Scandinavian media industry and higher education for journalists contributed to creating common professional perceptions of news conventions and "good journalistic practice". It also drew boundaries against other types of communication, such as public relations and marketing. A vital institutional feature also deals with notions about journalism as beneficial to society, which tends to be couched in self-imposed tasks such as societal information, stimulation of public debate, and critical scrutiny of those in power. The myth of journalism as a "fourth estate" (or fourth branch of government) has long been important for the legitimacy of the news media branch and for journalism as an occupation and enterprise (Roppen \& Allern, 2010; Raaum, 1999).

In line with this reasoning, Høyer (2005, p. 10) described "the news paradigm" as a shared understanding of news values, basic genre rules, and tacit conventions about how news should be presented. Internationally, theories of news values have resulted in attempts at creating lists of the most important news factors. ${ }^{5}$ However, a significant limitation of such lists is a tendency to overlook the significance of audience orientation and market strategies concerning newsrooms' specific priorities and news frames. While journalists 
in different media organisations may adhere to similar perceptions of general news values, their selection of stories and practical interpretations of newsworthiness may still vary. Moreover, international, national, and local news outlets must adapt to different audience expectations (Allern, 2002). In other parts of the news market, exclusivity is also an important goal in the newsroom, an aim for individual journalists, and a means to achieve recognition from peers within the journalistic profession (Willig, 2011).

Therefore, editorial organisations may represent different journalistic cultures and styles of reporting, which might influence their specific interpretation of news values. As mentioned above, both Aftonbladet and VG are popular news outlets, representing the "tabloid" tradition; crime, scandal, sports, and popular entertainment are an important part of the daily menu, but this is combined with reports and commentary about politics, current affairs, and culture. While all media - to some degree - use personification in their news reporting, commercial popular journalism prioritises, to a greater degree than other news outlets, what can be personalised and dramatised. As Eide (1995, p. 44-45) summed up in an analysis of two popular Norwegian news outlets, "It's all about people, experiences and feelings". Concerning news priorities and narrative techniques, "tabloid" newspapers (and their current online news sites) have usually represented a more dramatic (and melodramatic) type of storytelling than the informational model historically associated with the "omnibus" newspaper tradition and news outlets catering for up-market niche audiences.

The popular press has traditionally played a leading role in the development of mediated political scandals, especially in cases where personal morality is spotlighted. Political scandals are also prioritised because they provide journalists with opportunities to link commercial news priorities and questionable methods to a higher purpose: criticising powerholders' norms transgressions, revealing something that has been hidden, and legitimising themselves as morally responsible mediators fulfilling an essential societal role (Allern \& Pollack, 2012).

In a book on reflections about the legitimacy of journalism, Rasmussen (2004) pointed to a latent contradiction between ethical prudence and the professional ideals of being pressing and investigative. Ethical norms and professional standards are not synonymous. An 
illustrative Norwegian example is VG's admired and infamous frontpage story about a man who killed his wife. ${ }^{6}$

The newsroom illustrated the case with a wedding picture of the couple. The picture was symbolically torn in two, and the headline was a well-known part of the traditional wedding vows: "Till death do us part". The front page was immediately regarded as skilled and effective professional journalism, both internally and in other Scandinavian newsrooms (Bjerke, 2005; Raaum, 1986, p. 123). However, many readers reacted differently and interpreted the front page as cynical and immoral. These reactions led to a spontaneous demonstration against $V G$ outside the newspaper's premises. Commercial news values and shared moral values were on a collision course. As a result, $V G^{\prime}$ s editors found it wise to apologize for the front page.

A conflict between "good journalism" and "good media ethics" also featured in the media coverage of a political scandal involving Tore Tønne, a former cabinet minister in Jens Stoltenberg's first government. The popular tabloid Dagbladet led the news race, starting on December 4, 2002. Following his departure from government in October 2001, he applied for and received three months' severance pay as a former minister. This scheme is intended as compensation if the person in question has no other job income during this period. Dagbladet showed that, in the same period, Tønne had worked for a large industrial company, later receiving a large "success fee" for this task. He was, therefore, accused of abusing public support schemes. The case dominated the Norwegian news landscape for two weeks after that, with frequent critical articles and commentaries. Then, on December 21, it was announced that Tønne had taken his own life. The media hunt abruptly ended.

His suicide also led to intense public reactions against the press. Initially, the revelation about Tønne and his "double pay" was generally considered an example of good investigative journalistic work. Inside the media branch, many reckoned that Dagbladet - the news leader in the case - stood out as a candidate for a journalistic award for its coverage. However, the overall amount of negative coverage was extensive, and in most articles, the accused was denied the benefit of the doubt.

The criticism levelled against the press was directed at what many readers perceived as a campaign-oriented and one-sided media hunt. Influential politicians joined the chorus. In response to these 
public reactions, the Norwegian Press Association commissioned three academics to review the media's role in the case. Some months later, they delivered a thorough, reflective, and critical report. One of their general conclusions was that "There must be limits to brutal, disrespectful and anti-human journalism, regardless of whether the person in question is guilty or not guilty" (Hjeltnes et al., 2003, p. 10). They also suggested that in sensational cases - when "the heat is on" in the newsroom - there is a need for counter-perceptions, alternative views, and an internal critical voice, characterised as the need for "a Devil's advocate, a cold brain inside the newsroom" (Hjeltnes et al., p. 83).

While this advice is sensible, following up on it is very difficult since it requires both an assessment and a decision from each independent publisher. The news media have no common super-editorin-chief. Discussions around editorial priorities and resource use are also far beyond the mandate of the ethical councils of the Swedish and Norwegian news media branches.

\section{Media ethics and the difficult art of verification}

As the British moral philosopher Bernard Williams (2002) summed up, the norm of truthfulness is of great importance in all human and social conditions, a prerequisite for dialogue and cooperation. In particular, he emphasised two central virtues of truth: accuracy and sincerity. Accuracy is about correctness, ensuring that what is said or written is as precise as possible and not false or misleading, while sincerity is about being sure that what is expressed is meant honestly (p. 44). If we doubt the sender's honesty, his or her credibility is undermined. In a discussion about the importance of these two virtues for media ethics, Phillips et al. (2010, p. 54) added a third: the virtue of hospitality (Silverstone, 2007), taking into account the importance of how the news media affect the conditions for dialogue between cultures and peoples.

At the same time, it is necessary to note an important difference between general public morality and media ethics. In the novel Immortality, Milan Kundera reminds the reader about a special journalistic privilege: "The power of the journalist is not based on his right to ask but on his right to demand an answer" (Kundera, 1991, p. 
110). The ideological justification of this "right" is based on the recognition of journalism as an independent institution with a societal mission. Press freedom, which in Sweden and Norway is based on constitutional rights, includes the possibility of publishing information that can damage the reputation of both individuals and organisations, i.e., a right to harm for the sake of the greater good.

However, this classic argument regarding the freedom and power of the press is sometimes distorted and interpreted as a possible defence for sensational storytelling. In the UK, it has regularly been used by representatives of the popular tabloid press as an argument for their notorious working methods and never-ending range of celebrity scandals of widely varying public interest (Davies, 2014). According to Paul Dacre (2008), the long-serving editor of the rightwing Daily Mail, the press "has the freedom to identify those who have offended public standards of decency, the very standards its readers believe in, and hold the transgressors up to public condemnation". An ethical problem with this pompous moral narrative is that it too easily confuses public interest with what interests the public. Moreover, ignoring the virtues of accuracy and sincerity in reporting undermines the transparency of journalistic work. The philosopher Onora O'Neill commented in the 2002 BBC Reith Lecture as follows:

If powerful institutions are allowed to publish, circulate and promote material without indicating what is known and what is rumour, what is derived from a reputable source and what is invented, what is standard analysis and what is speculation, which sources may be knowledgeable and which are probably not, they damage our public culture and all our lives. (Cited in Phillips et al., 2010, p. 61)

In journalism, truthfulness is usually interpreted as a duty to report with a basis in reality and fact-checked information. Paragraph 1 of The International Federation of Journalists' (IFJ) Global Charter of Ethics reads as follows: "Respect for the facts and for the right of the public to truth is the first duty of the journalist" (IFJ, 2021). Questions related to the authenticity, credibility, and reliability of sources are regarded as essential to the information quality of journalism. Such ethical demands also play a crucial role in the boundary work of news media organisations towards other types of mediated communication. As Kovach and Rosenstiel (2007) underlined in their influential 
book about the elements of journalism: "In the end, the discipline of verification is what separates journalism from entertainment, propaganda, fiction, or art" (p. 79). In a textbook on ethics for journalists, Brurås (2006, p. 298) characterised truth as "an overriding requirement, in the sense that all other qualities of a good story become irrelevant if they are not true".

However, concepts such as truth or truthfulness are not directly mentioned neither in the Swedish nor in the Norwegian ethical codes of the media branch. Instead, a key concept is the truth-related virtue of accuracy, i.e., an obligation for journalists to present correct factual information from credible sources. One reason for avoiding "truth" as a concept may be that the ethical councils of the media branch have a limited assignment. They are not fact-finding institutions and never conduct any independent investigations in complicated and disputed cases. How media organisations prioritise news and frame their news stories is also outside their mandate and realm of interest (Bjerke, 2011). The role of the media's ethical councils when complaints against published articles or programmes have been submitted is to organize a review process and decide whether the media organisation has followed the established procedures for "good press practice" described in their ethical codes.

How such formulations are interpreted in relation to the virtue of accuracy is another story. In a discussion on press ethics in Norway, Bjerke (2011) pointed to the difference between two different levels of accuracy. On a simple report level, the quality demand is limited: citations from identified and seemingly trustworthy sources must be correctly rendered. We may call this "level 1 ". The ethical problem is that this basic type of control is insufficient in many situations and journalistic reports. As a result, media sources sometimes provide inaccurate, biased, or misleading information. This lack of a serious verification process obviously applies to politicians and other power players, and the documented stream of lies from the 45th president of the United States is just one, albeit extreme, example. Verification, which may be called "level 2", represents a more demanding factchecking process. Finding relevant and reliable evidence generally requires information from different, independent sources, and that this information is subject to critical scrutiny. However, an independent verification process is costly and time-consuming. In ordinary day-to-day journalism, thorough fact-checking is not, in prac- 
tice, a requirement before publication, according to Bjerke (2011, p. 129) in an analysis of the Norwegian press ethical system.

It is also evident that accuracy on "level 1 " is inadequate in all cases where sources promote claims that, if published, may publicly harm the accused. "Naming and shaming" scandals during the \#MeToo movement are a new reminder of the importance of verification processes in serious journalistic work.

\section{Benny Fredriksson's lost honour}

Benny Fredriksson was, until his resignation on December 8, 2018, the CEO of one of Stockholm's most important cultural institutions, Kulturhuset Stadsteatern (Stockholm House of Culture \& City Theatre). During earlier stages of his career, he worked both as an actor and a stage director. In 2002, Fredriksson became Stadsteatern's manager and CEO and remained the top leader of the theatre and its administration for fifteen years.

The front-page story that led to his downfall was published December 5, 2017, by Aftonbladet's online edition (aftonbladet.se). An abridged version of the article was published in the printed edition of Aftonbladet the following day (Kerpner, 2017). The newspaper's advertising placard for this issue, visible at newsstands all over Sweden, had the following text:

\section{THEATRE DIRECTOR PRESSURED actor TO ABORTION FOR A ROLE Employees paint a reign of terror by the CEO of Kulturhuset. "Eve- ryone is afraid of him."}

Aftonbladet claimed that their case presentation was based on 40 testimonies from past and present staff members about Benny Fredriksson's "reign of terror". An anonymous source was quoted as saying: "You may not openly quote me. He would deliberately go in to crush my career" (Kerpner, 2017). The only identified source in the news article was a former employee who had served as Fredriksson's secretary more than ten years prior. All other citations and claims were based on anonymous sources.

Fredriksson was described as a person with "a double nature", and one of the examples mentioned was that he once advised an 
actress "to have an abortion if she wanted a particular role. She had the abortion and got the role" (Kerpner, 2017). This part of the story, together with claims that he had failed to intervene against male actors responsible for sexual harassment, made it possible to frame the critique as part of the \#MeToo movement.

The \#MeToo framing was also underlined in an editorial by Eva Franchell (2017) and a column written by the newspaper's cultural director, Åsa Linderborg. An online version of her commentary was published on December 5, 2017, entitled "He has run the business with horror and fear". An almost identical text was published in the paper on December 6, 2017, under the headline "Politicians closed their eyes to Fredriksson's reign of terror" (Linderborg, 2017a). In the online column, she wrote that "He has pressured actors not to take parental leave. He has even forced an actress to have an abortion". In the printed newspaper column, the words "forced an abortion" were deleted. However, in another commentary, Linderborg (2017b) criticised a Facebook text published by Johan Wirfält, one of Kulturhuset Stadsteatern's middle managers, who criticised Aftonbladet's attack on Fredriksson. She dismissed his objections as follows: "With all due respect, but it is not Wirfält's womb that Benny Fredriksson has made demands on."

Aftonbladet's publications were reported to the Press Ombudsman in 2018 by his widow Anne Sofie von Otter and two sons. The PO summarised their main criticism in four points:

- Aftonbladet had not given Benny Fredriksson a real opportunity to respond to the accusations before the publication

- The newspaper had not published any statements which were to Benny Fredriksson's advantage

- Aftonbladet had not checked the accuracy of the accusations

- The accusations were summarised with a choice of words that gave them another and more serious significance

After organising a round of written answers and comments between Aftonbladet and the complainants, the PO assessed the case. In a detailed review, he especially criticised the lack of evidence concerning several serious accusations, including undocumented claims from anonymous sources, which were presented without reservation by the newspaper. He concluded that Aftonbladet had inflicted unjustifiable publicity damage on Benny Fredriksson and 
should be held accountable for this. He then handed the matter over to the PON for assessment and decision-making.

In the introduction to its assessment, the PON (2019) underlined that a person who is the head of an important cultural institution is "a person in power who must accept a harsh and thorough examination of the responsibilities that come with leadership". However, Aftonbladet's publications "consist predominantly of a series of accusations against Benny Fredriksson regarding individual events as well as sweeping and insulting descriptions of him as a person". PON assessed that the publications about Benny were flawed in several respects. The stories were, with one exception, anonymous, and it appears as if they were part of a petition: "It is not stated, except in one case, when the allegations should have occurred, and it is not clear whether the newspaper has been in contact with the informants." These circumstances "show that Aftonbladet has not done enough to investigate the information and the newspaper has thus had no basis for publishing such serious accusations".

Furthermore, PON concluded that Benny Fredriksson was not given a reasonable opportunity to respond. The main conclusion was as follows:

The Press Council thus shares PO's assessment that Aftonbladet has inflicted unjustifiable publicity damage on Benny Fredriksson. This is a serious press ethics violation, which is also reinforced by the fact that the publication has taken place on a broad front and includes not only the news part but also the editorial and cultural pages.

In summary, this means that Aftonbladet has grossly violated good journalistic practice.

In the preface to an anthology on media ethics and public shaming, Truedson (2020, p. 10) summed up that Aftonbladet's publications about Fredriksson "developed into one of the most tragic and shocking cases Swedish media ethics has ever experienced". How could it happen?

In a detailed review of the case, Torbjörn von Krogh (2020) pointed to some factors that seemed to have played a significant role. As Rosenvinge (2020) documented, one such factor was that Aftonbladet had fallen somewhat behind other news outlets in the commer- 
cial competition for sensational \#MeToo-related revelations. As if this was not enough, the \#MeToo story prioritised in Expressen, Aftonbladet's main competitor, were accusations against one of Aftonbladet's well-known reporters and editorial commentators, Fredrik Virtanen. The freelance writer and social media activist Cissy Wallin accused him of rape. ${ }^{7}$ Internal contradictions and critique had also led to a leadership crisis inside the news organisation. On December 4, 2017, the responsible publisher and editor-in-chief, Sofia Olsson Olsén, reported being sick because of a stress reaction. She never returned to the newspaper.

In the last part of November 2017, Åsa Linderborg was contacted by employees of Stadsteatern, who, in the wake of the \#MeToo movement, wanted to launch a critique of Benny Fredriksson's leadership methods. After she had spoken with a few sources, the follow-up was left to Aftonbladet's newsroom (von Krogh, p. 27). The launch of their accusations apparently gave Aftonbladet a unique opportunity to recapture lost ground in the ongoing news competition, and their dramatic news story attracted national attention. Immediately preceding this publication, Linderborg (2017c) penned an indignant column about Expressen's speculations about \#MeToo and Aftonbladet. She characterised it as motivated by an "unrestrained aggression in the pursuit of market shares". Unfortunately, this also seems to be a precise summary of Aftonbladet's lowering of the ethical news threshold in the Benny Fredriksson case.

\section{Trond Giske's scandalised bar dance}

In early December 2017, two leading Norwegian news outlets, Dagens Noringsliv and VG, wrote that the Labour Party's leadership had received \#MeToo-related alerts from several women about Trond Giske, one of the party's deputy leaders. The claims in the alerts were that Giske had previously exposed them to unwanted sexual advances. Two of the women later stood forward and publicly presented their case. Giske generally denied that he had sexually harassed the women but regretted that he had sometimes behaved in a way that individuals had perceived as inappropriate or unpleasant. According to an internal party summary of Giske's commentary to one of the cases, he "admits that he was too drunk and that his 
behaviour was inappropriate both in terms of his position and the age difference between them ... He has given the woman his unreserved apology".

However, Giske also characterised other alerts as baseless and false. The party leadership, however, concluded in their assessment that, on several occasions, he had violated the party's internal guidelines. As a result, he lost his position in the central leadership of the party.

Despite this, Giske continued to be trusted by many party colleagues in Trondheim, his local constituency in mid-Norway (Sletteland \& Orgeret, 2020, s. 81). From both inside and outside the party, suspicions were also raised about alarms of sexual harassment being used in an internal power struggle. As in other mediated scandals, the extent, intensity, and one-sidedness of the media coverage led to some counter-reactions and sympathy among the general public.

Around a year after his downfall, in February 2019, Giske was proposed by the local election committee to be the elected deputy leader of the Labour Party in Trøndelag, a county in which Trondheim is the largest town. This position would also give him a place in the national party leadership. Political observers and pundits interpreted the proposal as an attempt at political rehabilitation.

Shortly after this nomination, Giske visited Vulkan Bar in his neighbourhood. A young woman, Sofie (27), who was celebrating her birthday with some friends, recognised him and spontaneously invited him to dance with her. ${ }^{9}$ He obliged. One of her female friends filmed the episode, and the six-second-long video was later shared privately among some of Sofie's friends. However, the video recording was also leaked to others, among them a local trade union official. He interpreted this as a new "\#MeToo affair", and without contacting Sofie, he sent a "message of concern" to the Labour Party's central leadership. The video was also leaked as a news tip to one of $V G$ 's journalists and “Giske hunters", Lars Joakim Skarvøy.

Skarvøy quickly contacted Sofie and organised a meeting with her about the video. On February 21, VG published an online article about the case. The main message, and frame, was a new "message of concern" to the Labour Party about Giske. The video recording was described as follows: "It shows that Giske hangs over the back of a woman in her 20s and places his hand on the woman's hip while they dance. The woman then bends away from Giske". Sofie, referred to as 
"the woman in the video", is cited as saying: "We danced and had a good time, then it became a bit much, so my friend and I left."

Following $V G$ 's publication, Sofie contacted NRK, the Norwegian public broadcaster, to challenge $V G$ 's representation of the case, and she said in an interview that the dance with Giske was "unproblematic and OK". Despite this quick public denial of $V G$ 's claims, the proposal to elect Giske to a new leadership position in the Labour Party in Trøndelag was immediately withdrawn, and Giske himself withdrew his candidacy.

In the weeks that followed, criticism of $V G$ 's working methods in the case increased, especially after an interview on March 20, 2019, with Sofie on TV2, one of the national TV channels. It also became known that, after Sofie's critical interview with NRK, $V G$ 's editor-inchief, Gard Steiro, called her personally. He repeatedly asked whether she had perceived the meeting with Giske as unpleasant, which she denied (PFU, 2019).

A few days later, on March 27, $V G$ presented a self-evaluation report about the case and admitted to violations of several paragraphs of the Norwegian media's ethical guidelines. However, $V G$ 's editors also presented journalist Lars Joakim Skarvøy's and Sofie's differing views about the disputed "citation" in the initial online article as two equal and alternative versions of what had been agreed in their meeting.

After a formal complaint from Sofie, The Press Complaints Commission (PFU) appraised the case on August 28, 2019 and concluded that VG had used "unacceptable methods" in its relations with a nonprofessional source (PFU, 2019). The critique from the PFU concerns both $V G$ 's publication about the Vulkan Bar case and its later selfevaluation report. According to the PFU, this represented a breach of good press practices concerning five paragraphs in the ethical codes, Voer Varsom-plakaten.

In the Spring of 2019, a committee was appointed by the Norwegian Press Association, with a mandate to bring about a broad investigation of the media's relationship with their sources, including some lessons from the VG case. The report was delivered in November the same year (Omdal et al., 2019). In his discussion about the Swedish and Norwegian \#MeToo cases, von Krogh (2020, p. 32) characterised such thorough and critical investigations of media ethics as "the tool Sweden lacks". Among the topics discussed were the media's relations with anonymous sources, premises concerning contacts 
between sources and interviewees, requirements for documentation, and citation rules. The committee also proposed some revisions in the ethical codes (Omdal et al., 2019). After a round of consultations and debates in the media industry, the board of the Norwegian Press Association adopted changes in five of the paragraphs, among other things clarifying the guidelines concerning identification, accuracy, allegations from anonymous sources, and citation control. It also included a warning against misusing inexperienced sources.

\section{Discussion and conclusion}

Journalists' relations with their sources have always been vital for news media content and the quality of journalism. The credo about journalism as a discipline of verification (Kovach \& Rosenstiel, 2007) underlines the importance of norms related to fact-checking and accuracy. Gross violations of such ethical rules, as the above cases illustrate, immediately lead to loss of trust in the newsrooms involved and endangers public trust in journalism as an institution. The sharp, professional criticism directed at Aftonbladet and $V G$, respectively, may therefore be interpreted as necessary "boundary work" (Carlson, 2015, p. 10), a demarcation against publication types and a journalism practice that cannot be accepted. It may also function as a confidence-building branch strategy.

A key question seldom discussed in relation to specific complaints is why journalists - and their newsrooms - are from time to time tempted to overlook elementary and well-known ethical rules concerning fairness and accuracy. Why do they lose their ethical foothold? One of the crucial factors is arguably an inherent conflict between different norms related to professional, market-driven journalism.

When particular types of news stories capture the public interest, such as the \#MeToo movement in the autumn of 2017, they immediately influence newsroom priorities. However, anonymous testimonies about sexual harassment and structural critiques of men's misuse of power are difficult to present as eye-catching and exciting human stories - especially after the first reports and headlines. Professional, market-driven journalism requires news stories based on concretisation and personification, and for popular journalis- 
tic media, this is more or less "a life-and-death matter". If such revelations can be presented as an attempt to hold powerholders to account, they also demonstrate the importance of another important professional norm.

Commercial news values provide the self-fulfilling impetus for the editorial hunting of stories linked to or directed at well-known persons, celebrities, and powerholders. Being the first newsroom to launch a political scandal may increase the organisation's professional prestige, and if other newsrooms follow up on this, it is regarded as a success among peers. That was exactly what happened after Aftonbladet's "scoop" about Benny Fredriksson; the story was followed up by many other news media outlets.

While Swedish media have gradually learnt to be more restrictive in publishing names, for example, in their crime reports (Pollack, 2020), the hunt for \#MeToo-relevant, personalised stories quickly lowered the threshold for publishing names in relation to allegations of sexual harassment. As Rosenvinge (2020) pointed out in an analysis of the first month of \#MeToo, whether names were published or not did not follow any logic or principal line; it could change from day to day on a case-by-case basis.

In major scandal cases, larger news media often compete for the leading role in the hunt. Without verification of these claims, Aftonbladet's willingness to publish a long list of defamatory accusations against Benny Fredriksson may first and foremost be interpreted as a desperate move to conquer a leading position in the \#MeToo news race. Even the editorial opinion and cultural pages were used in the attack, a strategy that should demonstrate the importance and seriousness of the alleged scoop. However, this also helped make the ethical violations more severe and resulted in a backlash that secured Aftonbladet's coverage of the Benny Fredriksson case a place in "the hall of shame" in the history of Swedish media ethics.

$V G$ 's Vulkan Bar story was also presented as a "sensational" story about a (former) powerholder, but the methods used became the most important ethical question: it was an attempt to create a "scandal" by manipulating a non-professional source and constructing a misleading citation. This practice represented a violation of norms about honesty and sincerity in relation to news media sources. The strong reactions from peers and the criticism from the media's ethical watchdog, the PFU, emphasised that this was a harmful act to the 
public and represented an undermining of the relationship between journalism and its sources.

Another common feature related to Aftonbladet's articles about Benny Fredriksson and VG's Vulkan Bar story about Trond Giske was the construction of these cases as \#MeToo-related. This intentional framing, without doubt, strengthened the commercial and political news value of the cases. However, both attempts were based on loose grounds. In the Benny Fredriksson case, this was based on unfounded claims and misrepresentation. Most of the potentially substantial critique - if Aftonbladet had researched the story - was how he exercised his power as a director and CEO, which was practically unrelated to personal stories of sexual harassment. In the Bar Vulkan case, the \#MeToo associations were based on misinterpretations of a harmless private dance episode - and a journalistic manipulation of a citation from an inexperienced source.

Journalists often highlight the ability to criticise powerholders' norms transgression as an important mission and the legitimacy of their craft. Therefore, the right to publish revelations that may harm others is also part and parcel of journalism ethics. However, the precondition for this right is that the publication is based on relevant, accurate information and that the framing does not distort the context of the case.

The global \#MeToo movement pointed to the widespread structural problem of sexual harassment, which was also the case in Sweden and Norway. Across the various sectors of working life, women were able to identify with the call. This perspective, however, was undermined in the public sphere when person-centred scandal stories about a few powerholders and media celebrities took over. The important political issues highlighted by the \#MeToo movement diminished in importance. Unscrupulous name publishing and lack of verification weakened public trust in journalism, resulting in a backlash against the public discussions surrounding sexual harassment. 


\section{NOTES}

1 In 2020, the PO was renamed the Media Ombudsman (MO), and the PON changed its name to Mediernas etiknämnd (the Media Council). The name changes were related to an extension of the institution's mandate: While the PO primarily assessed ethical cases related to the printing press and their online outlets, the MO assesses ethical cases related to print media, radio, television and online media. Before 2020, a public institution, The Review Board for Radio and Television (Granskningsnämden for radio och tv), assessed all ethical complaints against radio and television channels in Sweden.

2 A few \#MeToo-related cases were assessed by The Review Board for Radio and Television, among them, a programme published by Swedish Television's investigative programme Uppdrag Granskning (UG), \#MeToo och Fredrik Virtanen. SVT/UG was criticised for invasion of privacy in relation to Cissy Walin, the person who had accused Virtanen of rape (Adelai \& Hill, 2019).

3 https://presse.no/pfu/ (PFU-sak 1987/18; PFU-sak 188/18 and PFU-sak 189/18).

4 Quotes from Swedish and Norwegian newspaper articles and documents were translated into English by the authors.

5 See Harcup and O'Neill (2017) and O'Neil and Harcup (2009) for an overview.

6 VG, January 19, 1983.

7 In 2011, Wallin reported Virtanen to the police on allegations of rape, which were alleged to have occurred in 2006. Virtanen denied this, and the case did not lead to legal action. In 2019, Wallin was sentenced to probation for gross defamation because of her public accusations.

8 Letter to the Labour Party's central board, cited by VG on January 2, 2018.

9 We base the presentation of the Vulkan Bar case on information provided to the PFU (2019).

\section{REFERENCES}

Adelai, A. \& Hill, S. (2019, September 2). UG:s program om metoo fälls i granskningsnämnden. SVT Nyheter. https://www.svt.se/kultur/ug-fallsfor-metoo-program

Allern, S. (2002). Journalistic and Commercial News Values. News Organizations as Patrons of an Institution and Market Actors. Nordicom Review, 22 (1-2), 137-152. 
Allern, S. \& Pollack, E. (2012) Mediated Scandals. In S. Allern \& E. Pollack, Scandalous! The Mediated Construction of Political Scandals in Four Nordic Countries (pp.9-28). Gothenburg: Nordicom.

Allern, s. \& Pollack, E. (2019) Källkritik! Journalistik i lögnens tid. Lund: Studentlitteratur.

Askanius, T. \& Hartley, J. M. (2020a) Journalistica temanummer: Kritiske perspektiver på \#MeToo i Norden: Journalistikken, debatten, bevægelsen. Journalistica, 1, 7-13.

Askanius, T. \& Hartley, J.M. (2020b) «Man ska' ju nødigt blive en kvinde med en sag». Rolleforhandlinger på redaktionerne i dækningen av \#metoo i Danmark og Sverige. Journalistica, 1, 71-97.

Bjerke, P. (2011). Journalistikkens vekst - ogfall? Om journalistisk profesjonsmakt. IJ-forlaget.

Bjerke, P. (2005). Det etiske tomrom i PFU. Norsk medietidsskrift, 4(12), 344349. https://www.idunn.no/nmt/2005/04/debatt_det_etiske_tomrom_i_ pfu

Brurås, S. (2006). Etikk for journalister (3rd ed.). Fagbokforlaget.

Carlson, M. (2015). Introduction: The many boundaries of journalism. In M. Carlson \& S. Lewis (Eds.), Boundaries of journalism: Professionalism, practices, and participation (pp. 1-18). Routledge.

Dacre, P. (2008, November 9). Society of Editors: Paul Dacre's speech in full. Press Gazette.

https://www.pressgazette.co.uk/society-of-editors-paul-dacres-speech-infull/

Davies, N. (2014). Hack attack: How the truth caught up with Rupert Murdoch. Chatto \& Windus.

Eide, M. (1995). Populærjournalistikk på norsk. Historiske noter om avisschizofreni. Norsk Medietidsskrift, 1(2), 43-56. https://www.idunn.no/ nmt/1995/01/populaerjournalistikk_paa_norsk

Franchell, E. (2017, December 6). Teaterchefen hotar och sprider rädsla. Aftonbladet, 2.

Hansson, K., Ganetz, H., Sveningsson, M.G. \& Sandgren, M. (2020) Legitimising a Feminist Agenda: The \#metoo-petitions in Sweden 2017-2018. Nordic Journal of Media Studies, 2(1): 121-132. DOI:10.2478/njms-20200011

Harcup, T. (2007). The ethical journalist. Sage Publications.

Harcup, T. (2020). What's the point of news? A study in ethical journalism. Palgrave Macmillan.

Harcup, T., \& O'Neil, D. (2017). What is News? News values revisited 
(again). Journalism Studies, 18, 1470-1488. https//doi.org/10.1080/14616 70X.2016.1150193

Hjeltnes, G., Brurås, S., \& Syse, H. (2003). 3 uker i desember: En kritisk gjennomgang av medienes rolle $i$ den såkalte Tønne-saken. Norsk Presseforbund.

Høyer, S. (2005) The Idea of the Book. In S. Høyer and H. Pöttker (eds.), Diffusion of the News Paradigm 1850-2000 (pp. 9-16). Nordicom.

IFJ. (2021). Global charter of ethics for journalists. International Federation of Journalists. https://www.ifj.org/who/rules-and-policy/global-charter-ofethics-for-journalists.html

Jortveit, I. N. (2018, December 21). PFU felte tre medier da utvalget behandlet årets eneste metoo-klage. Journalisten. https://journalisten.no/ingridnergarden-jortveit-metoo-pfu/pfu-felte-tre-medier-da-utvalget-behandlet-arets-eneste-metoo-klage/345136

Journalistförbundet. (2021). Rules of professional conduct.

https://www.sjf.se/yrkesfragor/yrkesetik/yrkesetiska-regler/rules-professional-conduct

Kerpner, J. (2017, December 6). 40 vittnesmål om Stadsteaterns vd:s skräckvälde. 'Diktatorisk maktutövare'. Aftonbladet, 8-9.

Kovach, B., \& Rosenstiel, T. (2007). The elements of journalism: What newspeople should know and the public shoud expect. Three Rivers Press.

Kundera, M. (1991) Immortality. Grove Weidenfeld.

Linderborg, Å. (2017a, December 6). Politikerna blundade för Fredrikssons skräckvelde. Aftonbladet, 4-5.

Linderborg, Å. (2017b, December 6). Utredningen verkar riggad för Benny Fredriksson, aftonbladet.se.

Linderborg, Å. (2017c, December 4). Thomas Mattsson som åklagare och tribunal. Aftonbladet. https://www.aftonbladet.se/kultur/a/0EnoL2/thomas-mattsson-som-aklagare-och-tribunal

Lindqvist, L. \& Ganetz, H. (2020) Brave women sound the alarm - representations of men and women in the Swedish media coverage of \#MeToo. Journalistica, 1, 14-46.

Omdal, S. E., Gerhardsen, A., Sannum, E., \& Sætre, S. (2019). Sa hun virkelig det? Medienes forhold til kildene. Norsk Presseforbund.

O'Neill, S., \& Harcup, T. (2009). News values and selectivity. In K. WahlJorgensen \& T. Hanitzsch (Eds.). The handbook of journalism studies (pp. 161-174). Routledge.

PFU. (2021). Code of ethics of the Norwegian press. PFU. https://presse.no/ pfu/etiske-regler/vaer-varsom-plakaten/vvpl-engelsk/ 
PFU. (2019). Sofie mot Verdens Gang, PFU-sak 099/19. PFU. https://presse. no/pfu-sak/099-19/

Phillips, A., Couldry, N., \& Freedman, D. (2010). An ethical deficit? Accountability, norms, and the material conditions of contemporary journalism. In N. Fenton (Ed.), New media, old news (pp. 51-67). Sage.

Pollack, E. (2020) Brottslighet och namnpublicering. In Truedsson, L. (Ed.) Uthängd - inte bara \#metoo (pp. 114-133). Institutet för mediestudier.

Pollack, E. (2019) “Sweden and the \#MeToo movement". In Interactions: Studies in Communication \& Culture, Vol. 20, Number 3, 185-200, Intellect

PON. (2019). Aftonbladet fälls för publicering om Stadsteaterns förre chef. https://medieombudsmannen.se/beslut/aftonbladet-falls-for-publicering-om-stadsteaterns-forre-chef/

Rasmussen, T. (2004). Mektig og aktverdig. Betraktninger om journalistikkens legitimitet. IJ-forlaget.

Roppen, J. \& Allern, S. (2010) Journalistikkens samfunnsoppdrag. In J. Roppen and S. Allern (eds.), Journalistikkens samfunnsoppdrag (pp. 11-34). IJ-forlaget.

Rosenvinge, T. (2020). Mediers beslutscircus under metoo drabbade enskilda och blev obegriplig för publiken. In L. Truedson (red.) Uthängd! Inte bara \#metoo (pp. 17-31). Institutet för mediestudier.

Ryfe, D. M. (2006). Guest Editor's Introduction: New Institutionalism and the News. Political Communication, 23(2), 135-144. https//doi. org/10.1080/10584600600728109

Raaum, O. (1999). Pressen er løs! Fronter i journalistenes faglige frigjøring. Pax.

Raaum, O. (1986) Pressens tøyelige etikk. Universitetsforlaget.

Sigvardsson, O. (2018, July 25). Därför fälls tidningar för tio metoo-publiceringar. DN Debatt. Dagens Nyheter. https://www.dn.se/debatt/darforfalls-tio-tidningar-for-metoo-publiceringar/

Silverstone, R. (2007). Media and morality: On the rise of the media polis. Polity.

Sletteland, A. (2018). Da \#metoo kom til Norge. Et ufullendte normskifte mot seksuell trakassering. Tidskrift for kjønnsforskning, 42, 142-161. https:// www.idunn.no/tfk/2018/03/da_metoo_kom_til_norge

Sletteland, A., \& Orgeret, K. S. (2020). Giskesaken og hvordan vi får \#metoo tilbake på sporet. Forlaget Manifest.

Sletteland, A., \& Orgeret, K. S. (2019). Game of Trond - en slagmarki kampen om \#metoo. Nytt Norsk Tidsskrift, 3(36), 204-218. https://www.idunn.no/ nnt/2019/03/game_of_trond 
Tandoc, E. C. Jr., Jenkins, J., Thomas, R. J., \& Westlund, O. (Eds.). (2021). Critical incidents in journalism: Pivotal moments reshaping journalism around the world. Routledge.

Truedson, L. (2020) Uthängd! - om medieetik bortom \#metoo. In L. Truedson (red.) Uthängd! Inte bara \#metoo (pp. 7-16). Institutet för mediestudier.

Von Krogh, T. (2020). Metoo och hanteringen av mediernas ansvar: Norge har det verktyget Sverige saknar. In L. Truedson (red.) Uthängd! Inte bara \#metoo (pp. 32-90). Institutet för mediestudier.

Williams, B. (2002) Truth and Truthfullness: An Essay in Genealogy. Princeton University Press.

Willig, I. (2011). Bag nyhederne - vaerdier, idealer og praksis. Forlaget Samfundslitteratur.

Zelizer, B. (2017). What journalism could be. Polity.

\section{SIGURD ALLERN}

Professor Emeritus

Department of Media and Communication

University of Oslo

sigurd.allern@media.uio.no

\section{ESTER POLLACK}

Professor

Department of Media Studies, Section of Journalism, Media and Communication Studies (JMK)

Stockholm University

ester.pollack@ims.su.se 